\title{
PERSPEKTIF SOSIOLOGI EKONOMI DALAM PEMUTUSAN HUBUNGAN KERJA KARYAWAN PERUSAHAAN DI MASA PANDEMI COVID-19
}

\author{
Neng Yayu Padaniah ${ }^{1}$, Haryono ${ }^{2}$ \\ ${ }^{1}$ Program Studi Pendidikan Sosiologi, Fakultas Keguruan dan Ilmu Pendidikan \\ ${ }^{2}$ Program Studi Pendidikan Sosiologi, Fakultas Keguruan dan Ilmu Pendidikan \\ Universitas Sultan Ageng Tirtayasa \\ ${ }^{1}$ yayupadaniyah99@gmail.com²haryono@untirta.ac.id
}

\begin{abstract}
ABSTRAK
Perkembangan dunia industri pada masa pandemicovid-19, di setiap perusahaan atau kaum pemilik modal selalu memprioritaskan kondisi perusahaannya agar tetap stabil. Pandemi covid-19 mengakibatkan sebuah perusahaan mengambil keputusan untuk memutuskan hubungan kerja dengan karyawannya (PHK), sebab perusahaan mengalami penurunan laba atau defisit (penurunan tingkat pendapatan). Tujuan penelitian ini yaitu untuk menganalisis pengaruh pemutusan hubungan kerja dalam perspektif sosiologi pada lingkungan masyarakat. Metode penelitian yang digunakan yaitu kualitatif deskriptif yang melibatkan proses penggambaran masyarakat setelah terkena PHK . Populasi penelitian yaitu masyarakat. Sampel ditentukan secara probability sampling dan diperoleh masyarakat yang terkena PHK dari kota kemudian kembali kedesa unuk mencari alternaif pekerjaan. Hasil wawancara dan obervasi diolah menjadi data oleh penulis. Hasil penelitian terdapat hubungan antara sosiologi ekonomi dengan masyarakat yang ter-PHK yakni ketika masyarakat sudah tidak lagi bekerja maka akan berdampak pada kondisi sosial-ekonomi, dan otomais tidak mendapat gaji secara tetap. Maka masyarakat harus mempunyai keterampilan atau usaha lain agar dapat memenuhi kebutuhan hidup guna mencapai kesejaheteraan
\end{abstract}

Kata kunci : Sosiologi ekonomi, pemutusan hubungan kerja, pandemi Covid-19.

\begin{abstract}
The development of the industrial world during the COVID-19 pandemic, every company or capital owner always prioritizes the condition of the company so that it remains stable. The COVID-19 pandemic has resulted in a company taking the decision to terminate employment with its employees (PHK), because the company experienced a decrease in profits or a deficit (a decrease in income levels). The purpose of this study is to analyze the effect of termination of employment in a sociological perspective on the community. The research method used is descriptive qualitative which involves the process of describing the community after being laid off. The research population is the community. The sample was determined by probability sampling and obtained by people who were laid off from the city and then returned to the village to look for alternative jobs. The results of interviews and observations are processed into data by the author. The results of the study show that there is a relationship between economic sociology and people who have been laid off, namely when people are no longer working, it will have an impact on socio-economic conditions, and automatically they do not get a fixed salary. So the community must have skills or other businesses in order to meet the needs of life in order to achieve prosperity Keywords: Sociology of the economy, layoffs, the Covid-19 pandemic.
\end{abstract}




\section{PENDAHULUAN}

Corona Virus Disease 2019 atau singkatannya (covid-19) adalah suatu virus yang sangat berbahaya yang bisa memberi dampak negatif siapapun dari anak bayi, remaja, dewasa, maupun lansia dan penyebarannya melalui percikan air liur, batuk, ataupun bersin. Virus tersebut berasal dari kota Wuhan, China bulandesember 2019 serta menyebarnya kesemua negara. Virus covid-19 tersebut masuk ke Indonesia pada maret 2020 menyebabkan pola kehidupan masyarakat di Indonesia mengalami perubahan baik dalam sektor pendidikan (pembelajaran jarak jauh atau dilakukan secara online), kesehatan (banyaknya tenaga medis yang dibutuhkan untuk mencegah penularan covid-19, ekonomi (melemahnya kondisi perekonomian masyarakat karena keterbatasan interaksi sosial secara langsung), perindustrian (beberapa perusahaan menjalani penurunannya produksi yang berefek dalam penurunan penjualan dan mengakibatkan terjadinya pemutusan hubungan kerja).

Keterikatanan para pekerja dan kaum pemilik modal terjadi ketika mereka memiliki kepentingan dalam dunia kerja. Pada dasarnya, ketika seseorang bekerja disalah satu perusahaan maka akan terjalin suatu interaksi sosial dan adanya berbagai kepentingankepentingan tertentu mengenai hubungan kerja. Dengan adanya hubungan kerja tersebut, dapat menimbulkan hak dan kewajiban antara pemilik perusahaan dan karyawan, akantetapi ketika sudah terjadi sebuah pemutusan hubungan kerja maka hubungan kerja tidak terjadi lagi. Selain itu, tidak adanya pola interaksi sosial saat seorang karyawan sudah terkena pemutusan hubungan kerja (PHK) disuatu perusahaan, tidak adanya hak dan kewajiban yang dipenuhi antara pekerja dan pemilik perusahaan.

Kewajiban serta hak tidak pada kumpulan kaidah ataupun peraturan, melainkan perimbangannya suatu kuasa pada wujud pada hak individu disatu manusia yang bercermin dalam suatu kewajibannya dipihak lawannya (Hermawan, 2012). Menurut pendapat penulis, hak dan kewajiban merupakan suatu hal yang dimiliki setiap individu berupa peraturan yang harus dijalankan setiap orang untuk mencerminkan kehidupan dari setiap individu.

Secara sosiologis, karyawan atau kaum proletariat merupakan orang yang terikat dengan aturan perusahaan. Sebab masalah terpokok yang biasanya di hadapi pada pendiriannya salah satu upaya yaitu pemodalan (Fitria, 2016). Sebagian besar tenaga kerja di Indonesia tidak memiliki keahlian secara khusus, maka dari itu dengan secara terpaksa mereka harus bekerja pada perusahaan orang lain. Realitanya dalam menciptakan hubungan yang harmonis dunia industri tidaklah mudah, bukannya terwujud akan tetapi malah terjadi ketegangan antar sesama karyawan ataupu nkaryawan dengan manajernya yang muncul dalam dunia industri tersebut. 
Pemutusan hubungan kerja berdampak signifikan, dimanapara karyawansetelah di PHK sudah tidak memiliki pekerjaan dan hanya mampu bekerja pada pekerjaan yang berstatus rendah. Kemudian, dilihat dari segi pendapatan, kondisi keuangan karyawan tidak stabil. Dari segi pendidikan, para karyawan rata-rata tidak berstatus pendidikan tinggi mereka hanya mampu menjadi buruh pada perusahaan orang lain. Sosiologi ekonomi yang mengkaji tentang bagaimana seorang individu atau aktor dapat mencukupi kebutuhan hidupnya guna mencapai kesejahteraan. Maka dari itu, seorang karyawan yang sudah terkena pemutusan hubungan kerja (PHK) secara otomatis sudah tidak mendapatkan upah secara tetap dan untuk melanjutkan hidupnya mereka memilih untuk membuka usaha kecil menengah (UMKM) untuk menunjang kehidupannya.

UMKM yaitu usaha yang produk alam di kembangkan untuk mendorog perkembangannya ekonomi dengan makro serta mikro di Indonesia serta terpengaruhi sektor yang lainnya dapat terus bertumbuh (Suci et al., 2017). Menurut pendapat dari penulis, UMKM adalah suatu usaha yang dimilik ioleh individu yang memiliki kemauan untuk membuka usaha guna untuk menunjang dan melanjutkan kehidupan.

\section{METODE PENELITIAN}

Metode penelitian yang digunakan adalah metode penelitian kualitatif deskriptif. Menurut Wahid Abdul Kudus (2020:81-82) seiring perkembangan penelitian kualitatif, nampak mengalami perkembangan teori dijadikan landasan dan tanpa melandaskan teori. Metode penelitian kualitatif yang melandaskan teori untuk memperkuat konsep tentang segala yang diteliti dan mengungkap realitas alam dan sosial yang sedang terjadi diarea penelitian. Penelitian yang sama sekali tidak menggunakan teorisemata untuk berupaya membangun sumber ilmu pengetahuan menjadi solusi terwujudnya temuan yang menghasilkan teori baru berdasarkan hasil penelitian.

Populasi, Menurut Sugiyono, (2016:80). Populasi yaitu suatu tempat, wilayah ,objek ataupun subjek yang akan di teliti meliputi: seseorang, kejadian, benda, nilai serta lainnya untuk mendapatkan sebuah informasi. Sample, Sugiyono berpendapat, (2016:81). Yaitu wujud pada skor serta karakter yang di miliki pada populasi.

Teknik Sampling di gunakan dengan Peneliti yaitu Probabiliity Sampling. Penelitian tersebut menggunakan teknik simple random sampling. Sugiyono berpendapat (2017:82) simple random sampling yakni pengambilannya anggota sampel pada populasi di lakukan dengan acak bias memperhatikan strata yang ada dalam populasi tersebut. Jadi, kesimpulannya dalam penelitian ini pengambilan anggota sample pada populasi di lakukan random tidak memperhatikan strata yang ada didalam populasi dan dihitung menggunakan rumus Slovin. 
Dalam mendapatkan data pada penelitian ini, peneliti melakukan perkumpulan data dalam step yaitu Wawancara (interview) serta Pengamatan (observasi).

\section{- Wawancara (interview)}

Sugiyono $(2017,194)$ berpendapat Wawancara di gunakan untuk tekhnik pengumpulannya data jika penelitilainnya melaksanakan studi pendahuluannya agar pendaptaran permasalahannya yang akan diteliti, serta apabila peneliti juga ingin mengetahui hal-hal dari responden yang lebih mendalam dan jumlah dari respon den tersebut sedikit. Pada penelitian ini wawancara di lakukan pada karyawan yang terkena PHK akibat efek pandemi covid-19 di antaranya: berinisial N (21), S (48) dan R (22).

\section{- Pengamatan (observasi)}

Dalampenelitian, suatu informasi kurang validitasnya jika diperoleh tanpa adanya pengamatan atau observasi. Menurut (Sugiyono, 2009: 203) dari penelitian Prof. Dr. Eri Barlian, MS, (2016) Pengamatan ataupun observasi yaitus alah satu strategi agar mendapat pengetahuan, jika di iringi pada pendekatan-pendekatan ilmiah yang menambahkan ketetapan salah satu informasi.

Jenis data yang dibutuhkan meliputi: data primer dan data sekunder. Menurut Sugiyono, (2016:136) data primer adalah data empirik yang di peroleh secara langsung dan lapangan penelitian yang bersumber dan informan sebagai sumber data. Menurut Sugiyono, (2016:138) data sekunder adalah data yang di peroleh dan studi kepustakaan, bahan-bahan dokumentasi dan instansi terkait, surat kabar atau bahan tertulis lainnya yang berhubungan dengan materi penelitian ini. Data yang di peroleh dalam penelitian ini di analisis dengan cara kualitatif deskriptif. Analisis kualitatif deskriptif digunakan untuk mendeskripsikan data yang diperoleh baik data primer maupun data sekunder yang selanjutnya di ikuti dengan penafsiran dan kesimpulan.

\section{HASIL DAN PEMBAHASAN}

Hasil dari penelitian yang dilakukan berupa observasi dan wawancara. Penulis menganalisis jumlahperkerja yang terserang pemutusannya hubungan kerja (PHK) pada perusahaan ataupun instansi untuk akibat terdapatnya efek pandemi Covid-19. Penulis juga menganalisis kondisi sosial dan ekonomi para pekerja yang terkena PHK, serta bagaimana cara agar para pekerja yang terkena PHK tersebut dapat memenuhi kebutuhan hidup untuk dirinya atau bahkan keluarganya ketika sudah tidak mendapatkan penghasilan atau pendapatan setiap bulannya secara tetap. Maka, pada penelitian tersebut peneliti membahas perihal masalah yang diambil pada pemutusan hubungannya dalam berkerja (PHK) akibat pandemi covid-19 dengan keterbatasan waktu, biaya, tenaga serta lain-lain. Penulis 
memilih 3 informan diantaranya: berinisial $\mathrm{N}$ (21), S (48) dan R (22).

\section{Penelitian Terdahulu}

Penelitian terdahulu merupakan salah satu acuan penulis dalam melakukan penelitian sehingga penulis dapat memperkaya teori yang digunakan. Dari penelitian terdahulu, penulis tidak menemukan penelitian dengan judul yang sama akan tetapi memiliki keterkaitan dalam penelitian terdahulu. Namun penulis mengangkat beberapa penelitian sebagai referensi dalam memperkaya bahan kajian pada penelitian penulis.

Berikut merupakan penelitian terdahulu berupa beberapa jurnal terkait dengan penelitian yang dilakukan penulis : (a) Judul tulisan dan nama penulis : Pekerja sosial industri dalam menangani permasalahan PHK didunia industri Indonesia dan Sunija, D. Anisa; Febriani, Septia; Raharjo Santoso; Tri Humaedi; Sahadi, (b) Hasil penelitian yang relevan dengan penelitian yang akan dilaksanakan : Pekerja sosial dan industri berpengaruh signifikan terhadap permasalahan PHK didunia industri Indonesia. Sedangkan, terdapat persamaan yakni independen dan dependen penelitian terdahulu dan penelitian yang akan dilaksanakan, yaitu: permasalahan PHK. Oleh karena itu, berdasarkan hasil penelitian terdahulu terdapat pengaruh yang signifikansi secara parsial maupun secara simultan terhadap penelitian yang akan dilaksanakan.

Peran Sosiologi Dalam Bidang Ekonomi
Sosiologi, menurut Soerjono Soekanto (2014:11). Sosiologi yaitu ilmu sosial berobyekkan yaitu warga setempat. Menurut pendapat penulis sosiologi yaitu ilmu yang membahaskan secara realitas ataupun fenomena dialami diruang lingkup masyarakat.

Ekonomi, Menurut Haryanto, (2019:15). Dengan definitif, ilmu ekonomi yaitu suatu ilmu dipelajari sebagaimana warga memproduksi komoditas ataupun barang dan mendistribusikannya pada peserta rakyat lainnya pada rangka terpenuhinya suatu kebutuhan.

Sosiologi Ekonomi, Menurut Haryanto, (2019:18). Sosiologi Ekonomi yaitu study yang mengetahui tentang caranya seseorang ataupun warga untuk memenuhi kebutuhan hidupnya mereka pada suatu benda serta jasa serta menggunakan pendekatannya ataupun perspektif analisias sosiologi.

Berdasarkan penjelasan diatas, penulis dapat menyimpulkan yakni ilmu ekonomi bila dilihat dari paradigma sosiologi. Setelah pekerja terkena PHK oleh suatu perusahaan maka akan berdampak pada fenomena sosial atau kenyataan sosial di masyarakat. Individu yang tadinya bekerja di perkotaan sebagai seorang buruh kini kembali keperdesaan dengan alasan telah terkena pemutusan hubungan kerja dan tidak memiliki pekerjaan. Fenomena sosial yang terjadi di masyarakat yaitu terdapat sedikit gesekan karena melihat individu menjadi seorang pengangguran. Informan yang penulis wawancarai berinisial S (48) menyatakan "berat 
rasanya ketika menjadi seorang kepala keluarga tapi tidak memiliki pekerjaan dan pasti menjadi cibiran masyarakat lainnya, tapi saya hanya bersifat legowo saja dan semoga saya memiliki pekerjaan yang utuh kembali".

Menurut Peni Chalid (2009:6-7) bila di lihat pada konteks perekonomian pada aspek distribusi, produksi, serta pangan, sosiologi melihat warga pada spektrum yang sangat lebar. Oleh karena itu, fokus sosiologi berarah pada aspek tingkah laku sosial yang tergerak pada pola yang memiliki makna tersendiri, sosiologi biasanya dipusatkan perhatiannya pada orientasi individu dalam lingkungannya serta sebagaimana tahapan orientasi ini dapat dipengaruhi oleh tingkah laku. Agar diperjelaskan perbedaannya dalam pandangan antar sosiologi serta perekonomian saat terlihat individual didalam konteks perekonomian, bias diilustrasikan melewati tingkah laku seseorang pada kerja tim.

\section{Pemutusan Hubungan Kerja Karyawan}

\section{Perusahaan}

Hubungan kerja pada hakikatnya merupakan hubungan antara karyawan dan orang-orang yang ada di perusahaan, misal manajer. Hubungan yang terjalin yakni adanya perjanjian kerja, dimana pihak ke-satu, karyawan mengikatkan dirinya kepada pihak lainnya yakni manajer agar bekerja untuk mendapatkan uang serta manajer menyatakan kesanggupannya dalam mempekerjakan karyawannya secara membayarkan upah Randi, (2020).
Beragam serta berbentuk PHK bisa di lihat pada total seseorang (pekerja) yang di berhentikan. Maka bisa dilihat di klasifikasi pada 3 ragam (Muslim, 2020) : (1) PHK individu, adalah pemutusannya keterkaitan kinerja yang memiliki sifat pribadi ataupun seorangan serta mempunyai batasan waktu. Misalnya PHK pribadi yaitu pensiun (berakhirnya hubungan kinerja ataupun massa kinerja karena factor usia), tetapi PHK individu bias terjadi sebelum pekerja pension yaitu dengan melakukan pelanggaran terhadap aturan yang ada di perusahaan kemudian diberikan sanksi pemberhentiannya ataupun pemutusannya kontrak pekerjaan. (2) PHK berkelompok, adalah pemutusannya kontrak kerja yang di lakukan pada orang banyak atau sekelompok pekerja. Contohnya yaitu pekerja mengundurkan diri dengan alasan lain misalnya minta kenaikan gaji. PHK kelompok dapat terjadi juga karena situasi tertentu. Kemudian sekarang, terdapatnya covid-19 mengakibatkan daya jual sepi pengunjung bahkan beberapa ada yang tutup. Maka hal ini bias terjadi dikarenakan menurunnya daya beli warga maka terpaksa instansi gerai penjualan melakukan PHK secara berkelompok. Beberapa perusahaan mengalami penurunan penjualan yang berakibat pada menurunnya proses produksinya mengakibatkan sejumlah karyawan telah di-PHK dalam beberapa jumlah setiap kelompok. Menurut Kun Maryati dan Juju Suryawati (2011:136) ada beberapa ahli yang menjelaskan tentang kelompok, antara lain: (a) 
Pauls B. Hortion mengungkapkan bahwasanya tim memiliki arti tiap berkumpulnya seseorang dengan fisik (contohnya, sejumlah tim yang lagi menanti bis kota). (b) Rioland L. Waren mengungkapkan bahwasanya 1 tim sosial tentang beberapa jumlah orang yang interaksi serta mempunyai motif berinteraksi yang bisa dipahami pada anggotanya dengan keseluruhannya. (c) Maiyor Pollak mengugkapkan bahwasanya tim sosial yaitu beberapa jumlah individu yang memiliki keterkaitan tanpa bidang kerangka strukturnya. (d) WillaHukcy mengungkapkan bahwasanya tim yaitu sesuatu wujud yang terdapat pada 2 individu ataupun melebihi 2 , memiliki keterkaitan serta interaksi ataupun komunikasi. (e) Robbert K. Merston mendefinisikan tim dengan sejumlah individu yang dapat interaksi sama pada motif yang sudah matang. (f) Macc Ifer serta Carles H. Page mengungkapkan bahwasanya tim sosial yaitu suatu kumpulan ataupun himpunan orang yang tinggal bersama. menurut pendapat penulis pada pemutusan keterkaitan pekerjaan pegawai yang dilakukan pada perusahaan termasuk dalam tim menurut “Maiyor Pollak mengungkapkan bahwasanya tim sosial yaitu sejumlah manusia yang berkaitan didalam kerangka". Artinya pekerja atau karyawan merupakan sekumpulan orang yang berhubungan dengan sebuah struktur (perusahaan) serta diatur oleh berbagai norma yang ada dalam struktur tersebut. Ragam PHK ke (3) Pemecatan secara massal: pemutusannya kinerja massal yaitu pemutusannya suatu pekerjaan yang dilakukan pada beberapa pekerja karena beragam faktor, missal penutupan kantor cabang yang mengakibatkan perusahaan melakukan PHK.

Berdasarkan penelitian yang penulis lakukan PHK pada inisialS (48) dan R (22) terjadi karena perusahaan mengalami penurunan produksi dan terpaksa mengurangi beberapa pekerja dengan cara melakukan pemutusan hubungan kerja guna menjaga kestabilan perusahaan yang dimiliki oleh kaum pemodal. Pada inisial N (21) instansi gerai penjualan mengalami penurunan penjualan yang berakibat pada pemutusan hubungan kerja. Ragam dan bentuk PHK termasuk pada PHK kelompok karena perusahaan dan instansi gerai penjualan melakukan PHK dengan kondisi tertentu yakni pandemi covid-19. Manajemen SDM yaitu tempat pada manajemen perusahaannya yang memfokuskan dirinya dalam unsur SDM. Tiap manajemen perusahaannya wajib dihadapi dengan masalah tentang cara kerja pegawai, maka di lakukan identifikasikan faktor yang dipengaruhi cara kerja pegawai itu. Lalu perusahaannya akan memilih tahapan kebijakannya yang dibutuhkan, hingga tujuannya, harapan serta sasaran perusahaannya bisa terwujud (Junianto \& Joko Sabtohadi, 2019).

Kinerja karyawan atau pekerja merupakan suatu yang sangat penting karena berkesinambungan pada sumber daya manusia dan hasil produksi yang akan didistribusikan pada distributor agen agar produk sampai 
ketangan konsumen. Pada saat pandemic covid19 perusahaan seharusnya dapat memaksimalkan kinerja para pekerja, mengingat banyak perusahaan yang melakukan PHK pada pekerja, maka berdampak pada pengurangan pekerja dan memaksimalkan pekerja yang tidak terkena PHK agar dapat hasil yang diinginkan (maksimal).

\section{Dampak Pandemi Covid-19 Bagi Perusahaan}

Pandemi covid-19 memberikan dampak pada dunia industri salah satuya pada perusahan-perusahaan, dampak ini juga memberikan suatu hal negatif pada pekerja, sebab pekerja terkena pemutusan hubungan kerja karena perusahaan mengalami penurunan penjualan akibat adanya covid-19.

Umumnya pada perusahaan mengikat para pekerjanya dengan 3 golongan : (1) Pekerja harian lepas : merupakan pekerja yang tidak mendapatkan jaminan apapun dari perusahaan, pekerja hanya mendapat upah pada saat bekerja dan ketika pekerja tidak bekerja maka tidak akan mendapatkan upah. (2) Pekerja kontrak : merupakan pekerja yang didasarkan pada perjanjian kontrak (berapa lama pekerja akan bekerja pada suatu perusahaan, misal : satu tahun). (3) Pekerja tetap : merupakan pekerja yang sudah melalui tahap sebagai pekerja harian lepas dan pekerja kontrak, kemudian pekerja diangkat jabatan oleh perusahaan sebagai pegawai tetap yang mendapatkan berbagai jaminan dari perusahaan seperti: jaminan BPJS kesehatan serta BPJS ketenagakerjaan.
Langkah awal yang dilakukan perusahaan yaitu melakukan PHK pada pekerja harian lepas terlebih dahulu, kemudian PHK pada pekerja kontrak dan terakhir pada pekerja tetap (tetapi hanya sebagian saja). Informan yang penulis wawancarai yaitu karyawan yang berstatus sebagai pekerja tetap, ia di PHK karena pihak perusahaan dengan sangat terpaksa mengurangi jumlah karyawan sebab perusahaan tidak dapat membayar upah dan untuk menjaga kestabilan perusahaan namun pekerja tetap diberi pesangon sebagai upah terakhir yang diberikan oleh perusahaan. Akan tetapi berbeda pada informan kedua, ia bekerja pada perusahaan dengan status kontrak. Pada bulan November 2020 ia terkena PHK sebab telah habis masa kontrak, biasanya perusahaan melanjutkan masa kerjanya, tapi karena adanya covid-19 perusahaan tidak melanjutkan masa kerja karyawan tersebut.

Perbedaan juga muncul pada informan ketiga, ia bekerja pada perusahaan yang bersifat CV bukan PT yang terdapat pada informan pertama dan kedua. Pada informan ketiga ia bekerja disalah satu Mall di kota Serang, ia terkena pemutusan hubungan kerja akibat covid-19. Pada dasarnya masyarakat diintruksikan untuk dirumah saja guna mencegah penularan covid-19 dan menerapkan 3M (mencuci tangan, memakai masker, serta menjaga jarak). Mall yang tadinya ramai pengunjung kini menjadi sepi akibat adanya covid-19 dan masyarakat enggan untuk bepergian terkecuali memiliki urgensi keperluan 
yang sangat penting. Maka dari itu, hal tersebut berdampak pada penjualan yang mengalami penurunan kemudian melakukan pemutusan hubungan kerja dengan para karyawannya.Urgensi kestabilan keuangan perusahaan atau sebuah instansi menjadi prioritas bagi sistem dan struktur perusahaan, pengusaha beserta jajarannya harus mengkondisikan keadaan perusahaan yakni dengan terpaksa mengurangi jumlah karyawannya. Awalnya perusahaan memberikan upah sebesar $75 \%$ kemudian mengalami penurunan menjadi 50\% hingga mencapai terjadinya pemutusan hubungan kerja (PHK). Maka, sangat memberikan dampak negatif terutama pada seorang ayah yang menjadi kepala keluarga karena terjadi disfungsi keluarga yaitu pada bidang ekonomi, dimana seorang ayah tidak dapat memberikan kebutuhan pokok (sandang, papan, dan pangan) secara maksimal atau bahkan berpengaruh pada biaya pendidikan seorang anak serta kesehatan keluarga.

\section{Kondisi Social-Ekonomi Masyarakat yang}

\section{Terkena Pemutusan Hubungan Kerja}

Masyarakat merupakans ekumpulan orang yang sudah menetap lama disuatu wilayah. Umumnya masyarakat memiliki kebudayaan yang menjadi ciri khas suatu daerah. Masyarakat terbagi menjadi dua: (a) Masyarakat perdesaan atau solidaritas mekanis merupakan masyarakat yang memiliki kesadaran kolektif, yang masih memegang utuh pada totalitas kepercayaan serta belum mengenal pembagian kerja. (b) Masyarakat perkotaan, berbeda dengan solidaritas mekanis, solidaritas organis yang umumnya terjadi pada masyarakat perkotaan menyandarkan pada sifat individualistis, serta sudah mengenal pembagian kerja. Durkheim mempertahankan bahwa kuatnya solidaritas organis itu digarisbawahi oleh pentingnya undang-undang yang bersifat memperbaiki, menyehatkan maupun yang bersifat memulihkan (restitutif) dari pada yang bersifatrepresif (Putra, 2014).

Lapangan pekerjaan didesa tidak seluas lapangan pekerjaan dikota, yang mana didesa masyarakat memiliki mata pencaharian sebagai petani (mengurus ladang atau sawah untuk kemudian ditanami sayur-sayuran, padi, ataulainnya). Alternatif pekerjaan yang ada didesa yaitu masyarakat dapat berdagang sembako untuk didistribusikan langsung kepada konsumen.

Berbeda dengan lapangan pekerjaan yang tersedia dikota. Saat ini kota menjadi prioritas utama bagi masyarakat desa karena mayoritas dikota terdapat perusahaan atau perindustrian yang menawarkan gaji lebih besar dari pada pada pekerjaan didesa. Masyarakat desa menganggap jika bekerja diperusahaan dapat menjamin dan memenuhi kebutuhan hidup.

Pandemi covid-19 yang saat ini sedang maraknya menjadi perbincangan masyarakat Indonesia memberikan dampak yang sedemikian rupa. Pandemi covid-19 berdampak pada penurunan tingkat produksi disuatu 
perusahaan. Hal tersebut berakibat perusahaan harus memilih jalan untuk melakukan pemutusan hubugan kerja (PHK) agar perusahaan tidak mengalami kebangkrutan karena jika tidak dilakukan PHK maka perusahaan tidak bias membayar gaji para pekerja.

Masyarakat atau individu yang terkena PHK kini merasa bingung karena tidak tahu bagaimana mencukupi kebutuhan hidup ketika sudah tidak mendapatkan gaji. Sehingga, dengan sangat terpaksa individu harus kembali kedesa (tempat asal) karena biaya hidup diperkotaan terlalu tinggi. Penuilis melihat kondisi social-ekonomi individu pada informan yang berinisial $N$ (21) saat ini dia kembali kedesa dengan memikirkan berbagai cara agar dapat memenuhi kebutuhan hidupnya dengan melatih dirinya berjualan online dalam bidang makanan yaitu membuka warung nasi.

Menurut penulis usaha saat pandemi yang lebih baik yaitu pada bidang makanan. Dalam kondisi apapun masyarakat pasti membutuhkan makan untuk menjaga kesehatan dan mempertahankan daya tubuh agar dapat beraktivitas kembali. Social distancing yang saat ini diterapkan oleh pemerintah juga masyarakat harus membuat interaksi terjadi secara tidak langsung. Interaksi social merupakan kunci semua hubungan dalam kehidupan social karena tanpa interaksi sosial tidak akan terjadi hubungan timbal balik secaralangsung. Bertemunya individu dengan individu yang lain secara tidak langsung akan menghasilkan pergaulan hidup dalam suatu kelompok sosial (Sungkowo Edy Mulyono, 2017). Untuk itu dalam kondisi dan situasi saat ini yang memanfaatkan teknologi serta mencegah penularan covid-19 harus adanya kemampuan secara digital dari individu untuk mengembangkan usaha yang dimiliki.

\section{Menciptakan Ekonomi Kreatif Guna Mengembangkan UMKM di Masa Pandemi Covid-19}

Ekonomi Kreatif, menurut Rochmat Ali Purinomo (2016:8). Ekonomi kreatif yaitu sesuatu konsep dalam merealisasikan pembangunan perekonomian yang memiliki kelanjutan pada kreativitasnya. Menurut pendapat penulis terwujudnya ekonomi kreatif bila mana individu memiliki ide dan gagasan untuk berinovasi. Globalisasi dan medernisasi kini telah masuk dalam kehidupan masyarakat serta memberikan dampak positif juga negatif. Dalam memperoleh informasi masyarakat dapat menggunakan bantuan internet dengan mudah dan praktis, dengan internet juga masyarakat dapat juga dapat mengembangkan usahanya secara online.

Berdasarkan permasalahan yang telah penulis paparkan diawal ketika perusahaan tempat pekerja bekerja melakukan PHK tentunya pekerja tidak memiliki upah secara tetap, namun pekerja memiliki kemampuan untuk membuka usaha kecil menengah yaitu pada makanan, Informan yang penulis wawancarai kini telah membuka usaha tersebut demi kesejahteraan hidupnya. Hal tersebut 
selaras dengan program pemerintah yaitu kartu pra-kerja yang dimana dapat melatih berbagai kemampuan guna meningkatkan proses penjualan makanan yang diminati khalayak banyak serta menarik minat dan meningkatkan daya beli konsumen.

Berikut penyelesaian pemutusan hubungan kerja ditinjau dari sosiologi ekonomi : (a) Perlu adanya pelatihan yang diselenggarakan pemerintah dalam mengembangkan UMKM agar individu dapat membuat usahanya semenarik mungkin. Perkembangan UMKM dengan basis digital jadi sesuatu cara lain sebagai alternatif bidang UMKM dimasa pandemi covid-19. Maka, sejauh ini pemerintah dalam Kementerian Koperasi serta UKM sedah menjalani usaha mendukung terjadinya perubahan secara digital, maka oleh itu pandemi covid-19 bisa menciptakan tumbuhnya ekosistem pada kewirausahaan secara digital. Pada konteks tersebut, kewirausahaan digital yaitu wujud berbisnis yang memanfaatkan kehebatan teknologi digital, saat berproses sampai saat pemasaran produk serta jasa Arianto, B. (2020).

Pada awal masa pandemi covid-19 pemerintah sebenarnya sudah menerapkan program kerja dalam mengembangkan UMKM melalui kartu pra-kerja yang di dalamnya terdapat pelatihan dan bantuan finansial. Memasuki revolusi 4.0 kini para pelaku UMKM dituntut untuk dapat memanfaatkan penggunaan teknologi dalam usahanya. Seperti penggunaan website untuk mempermudah proses jual-beli antara konsumen dengan produsen. (b) Selaras dengan bantuan UMKM yang diberikan oleh pemerintah maka individu yang terkena PHK diharapkan mampu memiliki keterampilan lain agar dapat memenuhi kebutuhan hidupnya secara efisien.

\section{Analisis Teori Konflik Karl Marx Tentang PHK}

Konflik, Menurut Hariyanto (2019:31). Konflik pada warga kapitalis, kelas borjuis menindas kelas proletar, yang dalam gilirannya bisa menjerumuskan kapitalisme kedalam revolusi darah. Maka disebabkan dengan warga itu alat produksi (mens offproduction) perekonomian berubahnya singkat. Akan tetapi, hubungan-hubungan sosial produksi ketinggalan. Mismatch antar-superstruktur dan basisnya mengakibatkan disrupsi dan konflik. Jadinya, modesoffproduction menanamkan benih untuk kehancurannya diri sendiri. Analisis perekonomani Marxkarenadalamwarga kapitalis berpusatdengan teori tenaga pekerja, hingga harga komoditas disamakan secara tenaga sertacurhatan buruh dalam memproduksinyahal tersebut.

Dalam teori Marx yaitu konflik yang membahas tentang warga borjuis serta proletar, dimana kaum borjuis yaitu kaum yang mempunyai alat-alat produksi ataupun pemilik modal serta kaum proletar yaitu individu yang takmempunyai alat-alat produksi ataupun seorang buruh. Menurut penulis saat kondisi pandemi covid-19 kaum borjuis tidak ingin mengalami gulung tikar karena mereka menginginkan keuntungan yang maximum dan 
memberikan upah yang minimum. Hal tersebut mengakibatkan kaum borjuis melakukan pemutusan hubungan kerja terhadap kaum proletar agar tetap mestabilkan kondisi perusahaannya.

\section{PENUTUP}

Kesimpulan

Implikasi pandemi Covid-19 terhadap ekonomi memerlukan perhatian serius. Terutama pada seorang kepala keluarga yang mengalami pemutusan hubungan kerja. Kondisi ini memungkinkan terjadi adanya disfungsi keluarga dalam bidang ekonomi. Perubahan kondisi sosial-ekonomi kini mengalami perubahan pasca pemutusan hubungan kerja (PHK). Langkah yang dapat diambil yaitu masyarakat diharapkan mampu memiliki keterampilan lain guna menunjang kehidupannya. Sosiologi merupakan disiplin ilmu yang mengkaji tentang perilaku masyarakat dalam bertindak. Dalam sosiologi ekonomi mengkaji perilaku masyarakat dalam melakukan kegiatan-kegiatan ekonomi seperti jual-beli dan lainnya. Dalam program pemerintah yaitu kartu pra-kerja yang di dalamnya memuat pelatihan dan bantuan finansial bagi para pelaku UMKM dalam mengembangkan usahanya. Pengembangan UMKM juga perlu berkolaborasi dengan dunia digitalisasi yakni memanfaatkan penggunaan internet sebagai platform untuk menunjang keberhasilan usaha yang dimiliki oleh pelaku UMKM agar usahanya memiliki daya tarik yang cukup tinggi terhadap konsumen.
Saran

Terkait saran-saran yang ingin disampaikan kepada beberapa pihak yakni untuk khalayak umum dan untuk pemerintah. Saran-saran ini diharapkan mampu menjadi masukan untuk pembuatan artikel ilmiah lebih baik lagi kedepannya. (a) Saran untuk khalayak umum: Memperbanyak literasi agar memperluas wawasan dan informasi, Melakukan persiapan agar lebih matang dan terstuktur. Mulai dari tahap penulisan, pengumpulan literature hingga proses observasi dan wawancara, Penggunaan teori yang tepat juga mempengaruhi hasil dari artikel ilmiah. Sebaiknya mencaritahu lebih banyak mengenai teori yang akan digunakan. (b) Saran untuk pemerintah: Dalam program pemerintah seperti kartu pra-kerja hendaknya disesuaikan dengan kebutuhan UMKM agar menghasilkan UMKM yang bermutu dan berkualitas dibidangnya.

\section{UcapanTerima Kasih}

Penulisan artikel ilmiah ini dapat terselesaikan dari bantuan dan dukungan pihak terkait dan penulis mengucapkan banyak terimakasih pada : (1) Allah SWT, yang sudah memberikan rahmat serta karunianya pada saya sehingga artikel ilmiah ini bias terselesaikan dengan tepat waktu, (2) Orang tua yang sudah memberikan dorongan serta harapan dalam menyelesaikan artikel ilmiah ini, (3) Bapak Rizki Setiawan, M.Si. Selalu dosen pengampu mata kuliah Seminar IImu Sosiologi, (4) Bapak Haryono, S.Pd., M.Si. Selaku dosen 
pembimbingnya, ()Informan sudah tersedia penulisn wawancara guna mendapatkan informasi terkait artikel ilmiah ini, (6) Seluruh teman-teman pendidikan sosiologi 2018 yang turut membantu atas kesediaannya dalam bertukar fikiran, informasi, serta memberikan motivasi, kritik, saran, dan lain-lain dalam pembuatan artikel ilmiah ini.

\section{DAFTAR PUSTAKA}

Chalid, P. (2009). SosiologiEkonomi. Jakarta: Center For Social Economic Studies Press.

Haryanto, S. (2019). SosiologiEkonomi. Jogjakarta: AR-RUZZ MEDIA.

Kudus, W. A. (2020). RisalahPenelitianllmiah. Tangerang: Media Edukasi Indonesia.

Maryati, Kun dan Juju Suryawati. (2001). Sosiologi. Jakarta: Erlangga.

Prof. Dr. Eri Barlian, MS. (2016). Metodologi Penelitian Kualitatif dan Kuantitatif. Padang: SukabinaPress.

RochmatAldy Purnomo, S. M. (2016). EkonomiKreatif Pilar Pembangunan Nasional. Surakarta: Nulisbuku.com

Sugiyono. (2016). Metode Penelitian Kuantitatif dan Kualitatif $R \& D$. Bandung: Alfabeta.

Sugiyono. (2017). Statistik Untuk Penelitian. Bandung: Alfabeta.

Soekanto, Soerjono. (2014). Sosiologi Suatu Pengantar. Jakarta: Rajawali Pers.

Fitria, T. N. (2016). Kontribusi Ekonomi Islam Dalam Pembangunan Ekonomi Nasional. Jurnal Ilmiah Ekonomi Islam, 2(03), 29-40. https://doi.org/10.29040/jiei.v2i03.3

Hermawan, A. (2012). Keseimbangan Hak Dan Kewajiban Pekerja Dan Pengusaha Dalam Mogok Kerja. Mimbar Hukum, 24(3), 418-
430. https://doi.org/10.22146/jmh.16119

Junianto, D., \& Joko Sabtohadi. (2019). Pengaruh kompetensi dan budaya organisasi terhadap kinerja karyawan pada pt. wahyu daya mandiri surabaya. 2, No. 1, 1-10.

Muslim, M. (2020). Moh . Muslim : " PHK pada Masa Pandemi Covid-19" 358. ESENSI: Jurnal Manajemen Bisnis, 23(3), 357-370.

Putra, B. S. (2014). Solidaritas Kehidupan Penambang Belerang Tradisional Di Kawah Ijen. Sosial Dan Politik, 9(116), 1-20.

Randi, Y. (2020). Pandemi Corona Sebagai Alasan Pemutusan Hubungan Kerja Pekerja Oleh Perusahaan Dikaitkan Dengan Undang-Undang Ketenagakerjaan. Yurispruden, 3(2), 119. https://doi.org/10.33474/yur.v3i2.6709

Suci, Y. R., Tinggi, S., \& Ekonomi, I. (2017). Perkembangan UMKM (Usaha Mikro Kecil Menengah) di Indonesia. Jurnal IImiah Fakultasi Ekonomi, 6(1), 51-58.

Sungkowo Edy Mulyono, B. P. (2017). Interaksi Sosial Anak Jalanan Dengan Teman Sebaya Di Yayasan Setara Kota Semarang. (Social Interaction With Street Children Peers in Yayasan Setara in Semarang). Jurnal Eksistensi Pendidikan Luar Sekolah (EPlus), 2(2), 164-172. https://doi.org/10.30870/e-plus.v2i2.2959

Sunija, D. A., Febriani, S., Raharjo, S. T., \& Humaedi, S. (2020). Pekerja Sosial Industri Dalam Menangani Permasalahan Phk Di Dunia Industri Indonesia. Prosiding Penelitian Dan Pengabdian Kepada $\begin{array}{lll}\text { Masyarakat, } & 6(3),\end{array}$ https://doi.org/10.24198/jppm.v6i3.2620 6 
